\title{
Effect of inbreeding on the "Club Foot" disorder in Arabian Pureblood horses reared in Italy
}

\author{
Lisa Comparini, Adriano Podestà, Claudia Russo and Francesca Cecchi* \\ Department of Veterinary Science, University of Pisa, Pisa, Italy
}

\begin{abstract}
Background: "The Club Foot" (or "Mismatched Foot") is an acquired or congenital flexural deformity of the distal interphalangeal joint, caused by a shortening of the musculotendinous unit of the deep digital flexor tendon.

Aim: The aim of this research was to detect the incidence of the disorder in Arabian Pureblood horses, attempting to understand its causes and to analyze a possible role of inbreeding in its expression. In this breed, in fact, the pathology is widespread because in the environment of origin, the rocky desert, a hard and almost goat's hoof is not disabling so the selection against this disorder has never been done.

Methods: Pedigrees were taken from 141 (reference population = RP) adult Arabian Pureblood horses (51 males and 90 females) belonging to eight Italian different farms during the period 1982-2017. For each horse, the presence or not of the disorder was observed and inbreeding coefficients $(F)$ was performed. Four grades of deformity were considered. Moreover, the environmental condition of each farm was considered: boxes, paddocks, nutrition, orientation, and hoof care and shoeing. The chi-square test was applied. Analysis of variance (ANOVA) was used to test the differences in the average inbreeding coefficient $(F)$ between affected and healthy animals, between sexes and between shod and unshod animals.

Results: Two grades of deformity were observed (I and II) which give less severe manifestations, with 28 females and 25 males $(37.59 \%$ of the examined horses) showing the disorder. No differences between males and females or between shod $(38.29 \%)$ and unshod $(61.70 \%)$ were observed. Environmental conditions do not influence the rate of pathology in the different farms, with a prevalence of the disorder ranging from $7.69 \%$ up to $100 \%$ on farm. The whole population (WP $=\mathrm{RP}$ and its genealogy) included 3,355 records subdivided in seven traced generations. One hundred and eighteen out of 141 horses (RP) were inbred $(83.69 \%)$. The average inbreeding coefficient $(F)$ in the $\mathrm{RP}$ was 0.095 . Inbreeding coefficient in RP was $<0.05$ in only 15 horses $(12.71 \%$ of inbred), whereas it was $>0.25$ in 28 horses (23.73\% of inbred).

Conclusion: High inbreeding coefficients were observed in all farms and in particularly in affected animals suggesting that high inbreeding coefficients increases the probability that the disorder occurs. Future works may include the study of the hereditability of the character, and the attempt to identify loci associated with the disorder.
\end{abstract}

Keywords: Arabian Pureblood horses, Club Foot disorder, Inbreeding, Incidence.

\section{Introduction}

The Arabians are commonly believed to be one of the oldest and most influential horse breeds in the world (Głażewska, 2004). Arabian Pureblood horse expresses their versatility in competing in several equestrian fields, including racing, western, dressage, reining, endurance, show jumping, eventing, and even driving (Sobczyńska, 2010). Originating in Saudi Arabia, the Arabian horse has been selectively bred by the Bedouin people who need horses with a small and hard hoof to best ride on a sandy terrain with significant amounts of fragmented rocky components (Schiele, 1970).

Horses used in equestrian disciplines are subjected to intense exertion, making the athlete's physical integrity a vital point, in order to optimize performance as well as to limit the onset of traumatic disorders. Several parameters are involved in choosing a subject for sport activities, one of the most important is the absence of any disorder or malformation of the limbs such as the "Club Foot" or "mismatched foot" that is defined as a flexural deformity of the distal interphalangeal joint, caused by a shortening of the musculotendinous unit of the deep digital flexor tendon (Hunt, 2011). According to O'Grady (2012), the hoof capsule is distorted and the palmar angle of the third phalanx is at least $60^{\circ}$ or more, and the horse is forced to walk on his toes. Most commonly, this condition affects the forelimbs, usually one, but, sometimes, both. This deformity is believed to result from mal-positioning of the fetus in the uterus, errors in the nutritional management of the mare during gestation, exposure to influence virus or, in some circumstances, a genetic link. In fact, it can be acquired or congenital (O'Grady, 2012). This pathology is widespread in the Arabian Pureblood horse breed because in the environment of origin, the rocky 
desert, a hard, and almost goat's hoof is not disabling so selection against this disorder has never been done. Nonetheless, the presence in a horse of mild symptoms of the disorder, that would still allow it to climb on rocky surfaces for a limited period before complete functional failure, is not compatible with optimal performance in equestrian disciplines as practiced in our country with a completely different terrain.

In the selection, the inbreeding is used as a mating method because it allows fixing the characteristics and traits of the best representatives of a breed. However, this method can produce inbreeding depression, which has been described as a potential animal welfare problem (Keller and Waller, 2002; Brzeski et al., 2014; Cecchi et al., 2016) reducing fertility (Langlois and Blouin, 2004; Gonzales-Recio et al., 2007; Sairanen et al., 2009) and can lead to a decrease in selection response for economic traits such as racing performance (Todd et al., 2018). As the creation of Arab horse was not based on crossbreeding, it is more exposed to inbreeding effects than other horse breeds (Budzyński et al., 1997). Mating which concluded in abortion exhibited a higher level of inbreeding, while those that were barren or ended in the death of the foal were characterized by lower average values of the inbreeding coefficient (Budzyński et al., 1997). The effects of inbreeding on morphological traits have been studied in different horse breeds highlighting significant inbreeding depression for several morphological traits in Spanish Purebred horses (Gómez et al., 2009) and in a Campolina horse population (Bussiman et al., 2018). On the other hand, Curik et al. (2003) in Lipizzan horse and Sierszchulski et al. (2005) in Arabian horse found no effect of inbreeding on morphological traits. Wolc and Balińska (2010) reported that inbreeding was associated with a decrease in whither height in Sieraków horse, but not in Dobrzyniewo and in Kobylniki horse. In Haflingers horse breed, a weakly reduction of circumference of chest due to inbreeding was observed by Gandini et al. (1992).

Due to the impact that the Club Foot can have on the health and performance of the horses, and the lack of knowledge on its genetic aspects, the aim of this preliminary research was to study the effect of inbreeding on this disorder.

\section{Materials and Methods}

Pedigrees and observation on the presence or not of the "Club Foot" disorder were taken from 141 adult Arabian Pureblood horses (51 males and 90 females) belonging to eight Italian different farms during the period 1982-2017. Subsequently, the family tree of each considered subject has been reconstructed, allowing to identify common ancestors and lines. The following parameters have been calculated, using the program ENDOG v4.8 (Gutiérrez and Goyache, 2005): the number of full traced generations, the maximum number of generations traced and the equivalent complete generations. The number of inbred, the inbreeding coefficient of the 141 horses $(\mathrm{RP}=$ reference population), the average inbreeding coefficients within the farms, within the two sexes and within healthy and affected animals and within shod and unshod animals were performed using CFC software (Sargolzaei et al., 2006). The distribution of inbreeding level in the population were analyzed and 10 different class level of inbreeding were considered: $0<F \leq 0.05 ; 0.05$ $<F \leq 0.10 ; 0.10<F \leq 0.15 ; 0.15<F \leq 0.20 ; 0.20$ $<F \leq 0.25 ; 0.25<F \leq 0.30 ; 0.30<F \leq 0.35 ; 0.35$ $<F \leq 0.40 ; 0.40<F \leq 0.45 ; 0.45<F \leq 0.50$ (Sargolzaei et al., 2006).

The presence or not of the "Club Foot" disorder was tested following these criteria: alignment of the front hooves, recognition of pathological signs through analysis of hoof axis, presence of dishing on the anterior hoof wall from the coronary band to the toe, hoof width, heel height, frog atrophy, and presence of laminitis symptoms. For each animal the grading system for the stages of the deformity proposed by Redden (2003) was considered (Table 1). Furthermore for each farm, we consider the environmental factors taken into account in the list proposed by O'Grady and Poupard (2003): box (walls, floor, type of bedding, and cleanout procedures); paddock (type of ground and the time spent by the animals within the paddock); nutrition (gross estimate of the type and amount of forages and concentrates); orientation (training activities); hoof care, and shoeing (Table 2).

Chi-square test (SAS-JMP software version 7.0, 2007) was used to verify the differences in the disorder

Table 1. Grading system for the stages of the deformity by Redden (2003).

\begin{tabular}{cl}
\hline Grade & Description \\
\hline Grade I & $\begin{array}{l}\text { The palmar angle of the third phalanx is } 3 \text { to } 5 \text { degrees greater than the opposing foot, with characteristic fullness } \\
\text { of the coronary band due to partial luxation (partial dislocation) of the second phalanx bone and coffin bone. }\end{array}$ \\
Grade II & $\begin{array}{l}\text { The palmar angle of the third phalanx is } 5 \text { to } 8 \text { degrees greater than the opposing foot, with growth rings wider at } \\
\text { the heel than at the toe. The heel will not touched the ground once trimmed to normal length. }\end{array}$ \\
Grade III & $\begin{array}{l}\text { The anterior hoof wall is dished-in, with growth rings at the heel twice as wide as on the toe. Radiographically, the } \\
\text { third phalanx exhibits demineralization and lipping along the apex. }\end{array}$ \\
Grade IV & $\begin{array}{l}\text { The anterior hoof wall is heavily dished and the palmar angle of the third phalanx is } 80 \text { degrees or more; the } \\
\text { coronary band has the same height at the heel as at the toe. Radiographically, the third phalanx is rounded due to } \\
\text { extensive mineralization and rotation may be present. }\end{array}$ \\
\hline
\end{tabular}


Table 2. Description of the environmental parameters considered in each farm.

\begin{tabular}{|c|c|c|c|c|c|}
\hline Farm & Box stall & Paddock & Nutrition & Orientation & Miscellaneous \\
\hline 1 & $\begin{array}{l}\text { Wooden walls. Walls: } \\
\text { concrete Bedding: } \\
\text { straw. Cleanout: once } \\
\text { a week. }\end{array}$ & $\begin{array}{l}\text { Medium grain soil, } \\
\text { uneven, with rocks and } \\
\text { crevices. Mares are kept } \\
\text { daily and return to box } \\
\text { stalls at evening. Stallions } \\
\text { are kept twice a week. }\end{array}$ & $\begin{array}{l}\text { Grass hay. } \\
\text { Concentrate: barley, } \\
\text { amount based on the } \\
\text { animal's breeding } \\
\text { condition. }\end{array}$ & Breeding. & $\begin{array}{l}\text { Poor hoof care on } \\
\text { most horses, no } \\
\text { shoeing or regular } \\
\text { hoof trimming. }\end{array}$ \\
\hline 2 & $\begin{array}{l}\text { Wooden walls. Walls: } \\
\text { concrete Bedding: } \\
\text { straw. Cleanout: daily } \\
\text { bedding change. }\end{array}$ & $\begin{array}{l}\text { Mixed sand with gravel, } \\
\text { even. All horses kept } \\
\text { daily, return to box stalls } \\
\text { at evening. }\end{array}$ & $\begin{array}{l}\text { Grass hay + alfalfa } \\
2-3 \text { times a week. } \\
\text { Concentrate: barley, } \\
\text { oats }+700 \text { gr mixed } \\
\text { flakes per day. }\end{array}$ & Breeding. & \\
\hline 3 & $\begin{array}{l}\text { Concrete walls, single } \\
\text { boxes for stallions } \\
\text { and non-breeders; } \\
\text { large box near the } \\
\text { pasture for the mares. } \\
\text { Floor: concrete. } \\
\text { Bedding: dried } \\
\text { shavings. Cleanout: } \\
\text { daily. }\end{array}$ & $\begin{array}{l}\text { Medium grain soil, } \\
\text { uneven, with terracing } \\
\text { and gravel in spots. } \\
\text { Stallions and horses in } \\
\text { training are kept daily, } \\
\text { return to box stalls at } \\
\text { evening. Mares do not } \\
\text { return to stalls. }\end{array}$ & $\begin{array}{l}\text { Grass hay }+ \text { alfalfa } \\
\text { hay twice a week. } \\
\text { Mixed pasture. } \\
\text { Concentrate: corn, } \\
\text { barley, locust beans, } \\
\text { oats, soy, mineral } \\
\text { salts, at morning and } \\
\text { evening, amount based } \\
\text { on breeding condition. }\end{array}$ & $\begin{array}{l}\text { Breeding. } \\
\text { Trekking. } \\
\text { Foal } \\
\text { training. } \\
\text { Endurance } \\
\text { racing. }\end{array}$ & \\
\hline 4 & $\begin{array}{l}\text { Concrete and } \\
\text { wooden walls. Floor: } \\
\text { concrete. Bedding: } \\
\text { dried shavings. } \\
\text { Cleanout: daily. }\end{array}$ & $\begin{array}{l}\text { Medium grain soil, good } \\
\text { leveling, sloping. Mares } \\
\text { are kept daily and return } \\
\text { to box stalls at evening. } \\
\text { Stallions are kept for } \\
\text { training } 1 \text { hour daily. }\end{array}$ & $\begin{array}{l}\text { Mixed hay. } \\
\text { Concentrate: at } \\
\text { morning and evening. }\end{array}$ & $\begin{array}{l}\text { Breeding. } \\
\text { Endurance } \\
\text { racing. } \\
\text { Shows. }\end{array}$ & $\begin{array}{l}\text { Good hoof care } \\
\text { and shoeing. }\end{array}$ \\
\hline 5 & $\begin{array}{l}\text { Wooden walls. Floor: } \\
\text { soil. Shelters near } \\
\text { the paddocks. No } \\
\text { bedding. }\end{array}$ & $\begin{array}{l}\text { Medium grain soil, even, } \\
\text { poor draining. All horses } \\
\text { are kept daily. }\end{array}$ & $\begin{array}{l}\text { Mixed hay, mostly } \\
\text { alfalfa. Concentrate: } \\
\text { foals and mares } \\
\text { fodder, also used for } \\
\text { stallions in winter; } \\
\text { otherwise, } 90 \% \text { oats } \\
+10 \% \text { barley for } \\
\text { stallions. }\end{array}$ & Breeding. & \\
\hline 6 & $\begin{array}{l}\text { Walls: concrete } \\
\text { and wood. Walls: } \\
\text { concrete, stone } \\
\text { and tuff. Bedding: } \\
\text { shavings. Cleanout: } \\
\text { daily. }\end{array}$ & $\begin{array}{l}\text { Medium grain soil, } \\
\text { leveled, on hillside. } \\
\text { Mares kept daily. Daily } \\
\text { hard ground training } \\
\text { session for the show } \\
\text { horses. }\end{array}$ & $\begin{array}{l}\text { Grass hay. } \\
\text { Concentrate: mixed } \\
\text { flakes. Three meals a } \\
\text { day for foaling mares } \\
\text { and horses preparing } \\
\text { for shows. Two meals } \\
\text { a day for the others. }\end{array}$ & $\begin{array}{l}\text { Breeding. } \\
\text { Shows. }\end{array}$ & \\
\hline 7 & $\begin{array}{l}\text { Solid concrete; } \\
\text { concrete barn walls, } \\
\text { wooden partitions, } \\
\text { open shelters near } \\
\text { the paddocks. Floor: } \\
\text { stone, guttered for } \\
\text { drainage. }\end{array}$ & $\begin{array}{l}\text { Even clay soil. Horses } \\
\text { kept daily, return to box } \\
\text { stalls at evening. }\end{array}$ & $\begin{array}{l}\text { Mixed hay with lots } \\
\text { of alfalfa. Morning: } \\
\text { carrots. About 1-1.5 } \\
\text { kg mixed flakes per } \\
\text { animal at morning } \\
\text { and evening, based on } \\
\text { breeding condition. }\end{array}$ & $\begin{array}{l}\text { Breeding. } \\
\text { Endurance } \\
\text { racing. } \\
\text { Trekking. } \\
\text { Foal } \\
\text { training. }\end{array}$ & $\begin{array}{l}\text { Plastic shoeing on } \\
\text { the front hooves. }\end{array}$ \\
\hline 8 & $\begin{array}{l}\text { Concrete and } \\
\text { wooden walls. Floor: } \\
\text { concrete. }\end{array}$ & $\begin{array}{l}\text { Medium grain soil, even, } \\
\text { poor draining. All horses } \\
\text { are kept daily. }\end{array}$ & $\begin{array}{l}\text { Mixed hay. } \\
\text { Concentrate: at } \\
\text { morning and evening. }\end{array}$ & Breeding & \\
\hline
\end{tabular}


incidence existing between males and females or between shod and unshod animals and to test if different environmental conditions can influence the rate of pathology in the different farms. Moreover, ANOVA was used to test the differences in the average inbreeding coefficient $(F)$ between affected and healthy animals, between sexes and between affected shod and affected unshod animals (SAS-JMP software version 7.0, 2007). The level of significance was $p=0.05$. Three different models were used with three different variables entered as fixed factors: sex in the first model, affected and healthy animals in the second model, and affected shod and affected unshod animals in the third model.

\section{Ethical approval}

"Committee on the Ethics of Animal Experiments of Minimally Invasive Surgery Centre" (Italian laws).

\section{Results}

Out of the total 141 examined subjects (Table 3) forming the basis for our survey, 51 were males and 90 were females; 127 were over 2-year old (45 males and 82 females) and 14 were under 2 -year old (six males and eight females). Out the total, 54 were shod animals and 87 were unshod animals.

Fifty-three subjects out of 141 displayed the deformity (37.58\% of the whole examined population). Out of those, 25 were males (two were under 2-year old) and 28 were females (two were under 2-year old). The total affected shod animals were $20(37.00 \%$ of shod animals and the total affected unshod were 31 (35.63\% of unshod animals). The lesion was observed in both males and females and no significant prevalence by sex or shod/unshod were observed. Two grade of deformity were observed, grade I and II (grade I: 42 animals; grade II: 11 animals) that give less severe manifestations in comparison to the deformity of grade III and grade IV (Table 1). By comparing the pedigree charts of subjects kept in the eight farms, we have been able to observe the presence (or absence) of affected subjects and phenotypically healthy subjects in the family trees, and to know the frequency of recurrence of the character. It also emerges that even phenotypically healthy parents will sire affected progeny. Moreover, a thorough examination of the data shows that the lesion is not displayed in every generation. As an example, the graphical representation of a pedigree of one affected horse of farm 5 is shown in Figure 1.

Analysis of the pedigrees of the 141 analyzed horses (RP) showed that the complete database results in 3355 records. Considering therefore the RP, 118 horses resulted inbred (83.69\%); only 15 horses of this (12.71\% of the inbred) showed an inbreeding value lower $5 \%$, while 28 horses $(23.73 \%$ of the inbred) showed an inbreeding value higher than $25.00 \%$. Twelve of them have a coefficient between 0.250 and 0.300 , nine between 0.300 and 0.350 , five between 0.350 and 0.400 , one between 0.400 and 0.450 , and one animal between 0.450 and 0.500 (data not shown). The maximum number of traced generations was 7 . The mean maximum generations and the mean complete generations were 5 and 3.11, respectively, while the number of equivalent generation traced (sum, on all the generations of the ancestors, of the ancestors' proportion known to every generation) was 3.65. Average inbreeding coefficient in the RP was 0.095 , varying from a minimum of 0.030 in farm $n^{\circ} 2$ to a maximum of 0.180 in farm $\mathrm{n}^{\circ} 8$ (Table 4). The percentage of inbred varied from $57.14 \%$ (farm 6) to $100 \%$ (farms 5 , 7 , and 8 ). The maximum inbreeding value in the eight farms $(F)$ (Table 4) ranged from 0.120 (farm 2) to 0.500 (farm 4). A great difference in the average inbreeding coefficient between healthy animals and affected animals was observed in all farms with the exception of farm 2 (Table 5). Average inbreeding coefficient was very low in healthy animals (ranging from 0.005 in farm 4 to 0.085 in farm 6) and very high in affected

Table 3. Data from the total sample population: rate of pathology among the sexes, by age and shoeing.

\begin{tabular}{lccc}
\hline Animals & $\begin{array}{c}\text { Total } \\
\mathbf{N}^{\circ}\end{array}$ & $\begin{array}{c}\text { Males } \\
\mathbf{N}^{\circ}\end{array}$ & $\begin{array}{c}\text { Females } \\
\mathbf{N}^{\circ}\end{array}$ \\
\hline Animals examined, or with known hoof conformation & 141 & 51 & 90 \\
\hline Total animals 2 years old or younger & 14 & 6 & 8 \\
\hline Total animals over 2 years old & 127 & 45 & 82 \\
\hline Total healthy animals & 88 & 26 & 62 \\
\hline Total affected animals & 53 & 25 & 28 \\
\hline Grade I & 42 & 20 & 22 \\
\hline Grade II & 11 & 5 & 6 \\
\hline Total shod animals & 54 & 20 & 34 \\
\hline Total affected shod animals & 20 & 8 & 12 \\
\hline Total unshod animals & 87 & 31 & 56 \\
\hline Total affected unshod animals & 31 & 10 & 21 \\
\hline
\end{tabular}


animals (ranging from 0.040 in farm 2 to 0.337 in farm 4). Moreover, significant differences in the average inbreeding value were detected between healthy and affected animals (average $F=0.042$ in healthy animals, versus average $F=0.182$ in affected animals; $p<0.01$ ). Concerning the presence of affected animals inside the all eight farms although the females are in greater numbers than the males, there are no significant differences among the sexes in the disorder prevalence in farm 1, 2, and 3 (Table 5). In the other farms, there is a higher percentage of affected males (farms 4, 5, and 6) or of females (farm 7). In farm 8, all the animals were males and were all affected. There are no significant differences between shod and unshod animals in the disorder prevalence in the total sampling (Table 3) and in each farm (Table 6) and there are no significant differences in the average inbreeding among affected shod animals and affected unshod animals.

\section{Discussion}

The "Club Foot" is a biological event challenging the history and the daily practice of horse breeding, and giving us significant insight into the entrepreneurial difficulties facing the breeders and the issues of social adaptation deriving from this condition. This proves particularly true and interesting of a world that the methods of modern experimental science have yet failed to penetrate efficiently. The empirical observations, the expectations, the craft, and the skills are all part of a cultural context that has not produced a tentative solution for decades. A genetic component must also be considered for acquired flexure deformities, as some mares consistently produce foals that develop a flexural deformity in the same limb as the dam or grand dam in which a similar deformity is present (O'Grady, 2012). In the present study, we have studied different families in order to lay a foundation for the naturalistic

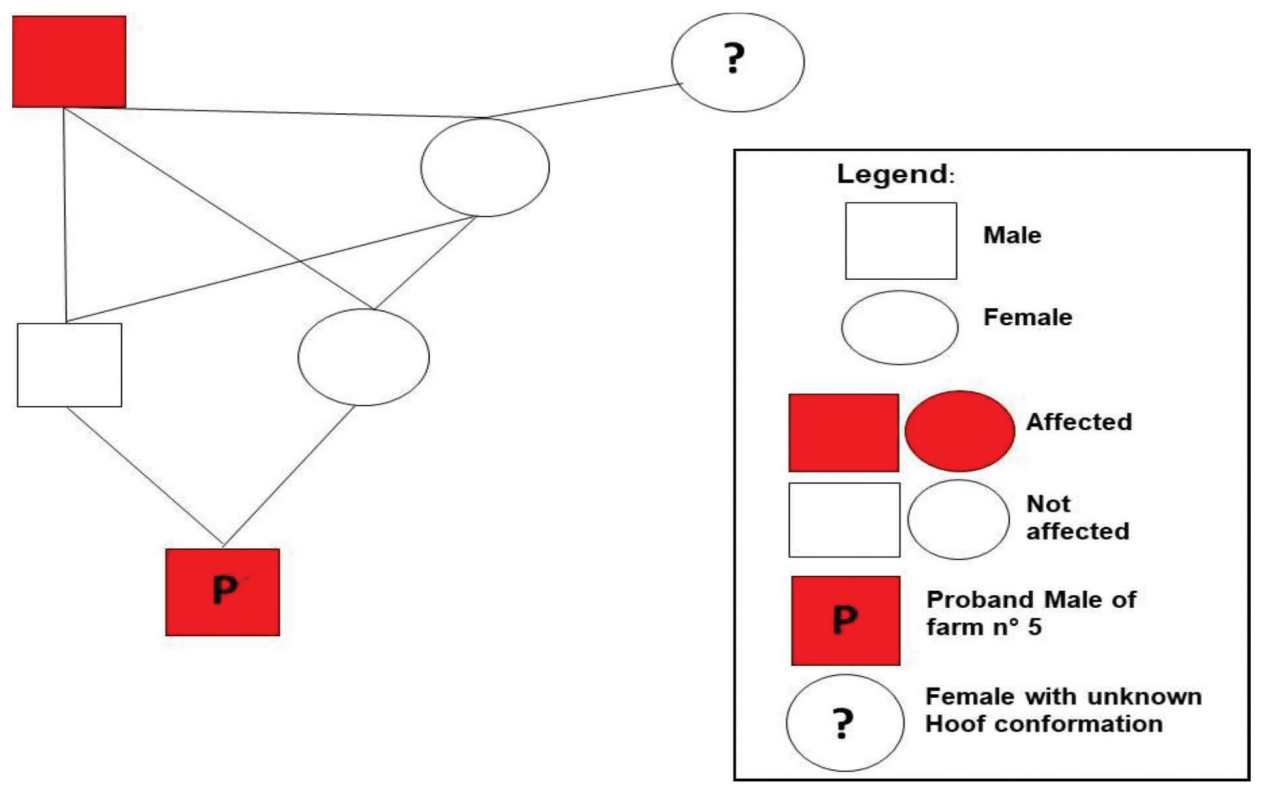

Fig. 1. Graphical representation of a pedigree of one affected male of farm 5.

Table 4. Analysis of inbreeding by farm.

\begin{tabular}{ccccccccc}
\hline Farm & $\begin{array}{c}\mathbf{N}^{\circ} \text { Total } \\
\text { animals }\end{array}$ & Average $\boldsymbol{F}$ & $\begin{array}{c}\mathbf{N}^{\circ} \\
\text { Males }\end{array}$ & $\begin{array}{c}\mathbf{N}^{\circ} \\
\text { Females }\end{array}$ & $\begin{array}{c}\mathbf{N}^{\circ} \text { Inbred } \\
\text { animals }\end{array}$ & $\begin{array}{c}\text { Average } \mathbf{F} \text { in } \\
\text { the inbred }\end{array}$ & $\boldsymbol{F}$ max & $\begin{array}{c}\text { \% Inbred animals } \\
\text { per farm }\end{array}$ \\
\hline $\mathrm{N}^{\circ} 1$ & 32 & 0.100 & 12 & 20 & 31 & 0.100 & 0.230 & 96.85 \\
\hline $\mathrm{N}^{\circ} 2$ & 18 & 0.030 & 5 & 13 & 13 & 0.050 & 0.120 & 72.22 \\
\hline $\mathrm{N}^{\circ} 3$ & 26 & 0.040 & 11 & 15 & 24 & 0.060 & 0.200 & 92.31 \\
\hline $\mathrm{N}^{\circ} 4$ & 29 & 0.080 & 5 & 24 & 20 & 0.110 & 0.500 & 68.96 \\
\hline $\mathrm{N}^{\circ} 5$ & 3 & 0.110 & 2 & 1 & 3 & 0.110 & 0.210 & 100.00 \\
\hline $\mathrm{N}^{\circ} 6$ & 14 & 0.050 & 6 & 8 & 8 & 0.100 & 0.200 & 57.14 \\
\hline $\mathrm{N}^{\circ} 7$ & 13 & 0.170 & 4 & 9 & 13 & 0.170 & 0.410 & 100.00 \\
\hline $\mathrm{N}^{\circ} 8$ & 6 & 0.180 & 6 & 0 & 6 & 0.180 & 0.370 & 100.00 \\
\hline Total & 141 & 0.095 & 51 & 90 & 118 & 0.110 & 0.500 & 83.69 \\
\hline
\end{tabular}




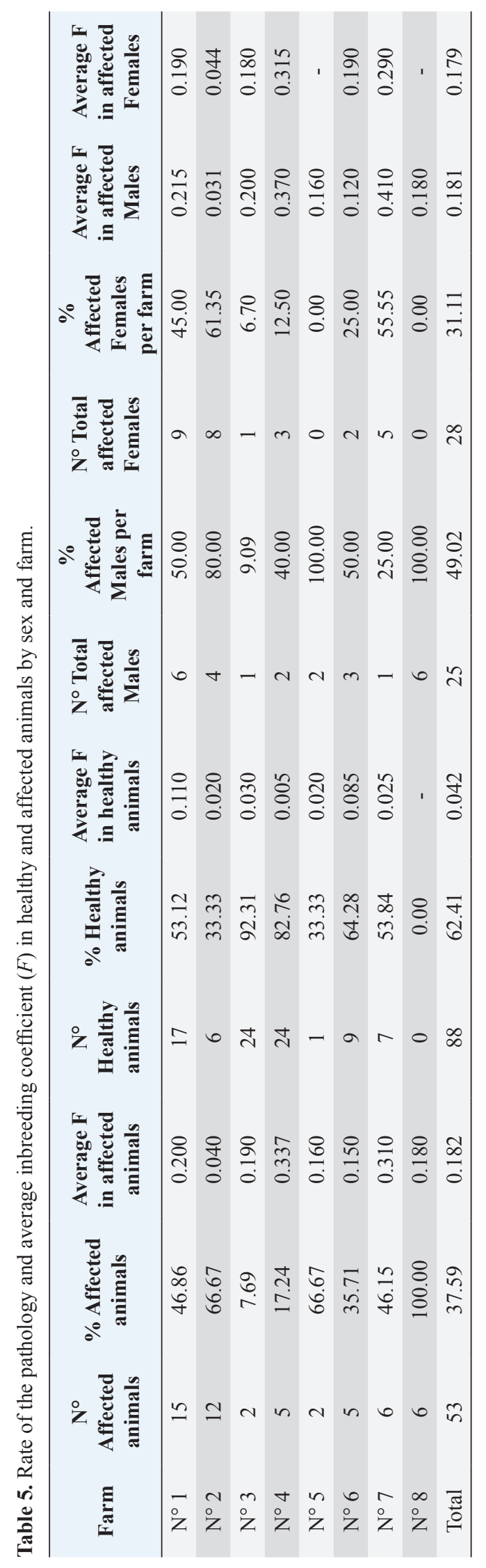

hypothesis that a genetic etiology can be found, which is responsible for the expression of a characteristic within a population. The high percentage of inbred in the RP and in each farm and the presence of many animals with high inbreeding coefficients values (higher than 3.125\% and even $40.00 \%$ ), showed an excessive use of the inbreeding as a mating method. In fact we must consider that values higher than $3.125 \%$ resulted from the mating of two animals sharing a single grandparent, while values higher than $40.00 \%$ correspond to the closest inbreeding, when breeding of brothers with sisters or parents with descendants takes places in several successive generations. High inbreeding coefficients were observed also in a previous research conduct on the Spanish Arab Horse (Cervantes et al., 2008).

Many other studies have reported inbreeding results in horse breeds and their analyses show that the mean coefficient of inbreeding differs for different breeds and within the same breed in different countries. The average coefficient of inbreeding observed in this population was similar to findings by Sairanen et al. (2009) for Standardbred trotters, and by Avdi and Banos (2008) for the endangered Skyros breed, but it was slightly smaller than those reported by Vostrá-Vydrová et al. (2016) in grey horses and in Black horses. Moreover, the average inbreeding values observed in some farms were higher than those found in some dog breeds (Ciampolini et al., 2013; Cecchi et al., 2018) that use commonly and notoriously inbreeding as a mating method. The main result that emerges in this research is certainly the great difference in the average value of inbreeding between healthy and affected animals that lets us to identify an important role of inbreeding for the expression of the disorder: high inbreeding coefficients increases the probability that the disorder occurs. Also, Dolvik and Klemetsdal (1994) found that Arthritis in the carpal joints of Norwegian trotter increased the probability of the disease of $6.70 \%$ and $12.30 \%$ among horses with, respectively, lower or higher inbreeding coefficients than the average. As well-known inbreeding can increase genetic diseases so we could assume a formal genetic pattern compatible with an autosomal recessive monogenic inheritance. As inbreeding can cause also "Inbreeding Depression," the polygyny of the condition cannot be ruled out entirely, since that will only be possible when the molecular identity of a single responsible gene can be fully described; it is still true that the our data do not point toward the influence of husbandry conditions nor of shoeing practices.

Actually, it emerges indisputably that the rate of pathology in farms with optimal environmental conditions is not significantly different from the farms where the quality of husbandry is limited by competence or budget reasons. If we analyze the rate of pathology, we find that the percentage of affected subjects has no relation between the disorder and shod or unshod animals. The same applies to the hoof care, the nutrition, the type of soil that the animals tread 
Table 6. Rate of the pathology and average inbreeding coefficient $(F)$ in shod and unshod animals.

\begin{tabular}{|c|c|c|c|c|c|c|c|c|}
\hline Farm & $\begin{array}{l}N^{\circ} \text { Shod } \\
\text { animals }\end{array}$ & $\begin{array}{c}N^{\circ} \text { affected } \\
\text { shod } \\
\text { animals }\end{array}$ & $\begin{array}{c}\% \text { Affected } \\
\text { shod animals } \\
\text { per farm }\end{array}$ & $\begin{array}{l}\text { Average } \\
F \text { in shod } \\
\text { animals }\end{array}$ & $\begin{array}{c}\mathrm{N}^{\circ} \text { Unshod } \\
\text { animals }\end{array}$ & $\begin{array}{c}N^{\circ} \text { affected } \\
\text { unshod } \\
\text { animals }\end{array}$ & $\begin{array}{c}\% \text { Affected } \\
\text { unshod animals } \\
\text { per farm }\end{array}$ & $\begin{array}{c}\text { Average } F \\
\text { in unshod } \\
\text { animals }\end{array}$ \\
\hline $\mathrm{N}^{\circ} 1$ & 10 & 4 & 40.00 & 0.087 & 22 & 8 & 36.36 & 0.106 \\
\hline $\mathrm{N}^{\circ} 2$ & 6 & 4 & 66.67 & 0.062 & 12 & 8 & 66.67 & 0.029 \\
\hline $\mathrm{N}^{\circ} 3$ & 5 & 0 & 0.00 & 0.072 & 21 & 2 & 9.50 & 0.033 \\
\hline$N^{\circ} 4$ & 22 & 4 & 18.18 & 0.108 & 7 & 1 & 14.28 & 0.057 \\
\hline $\mathrm{N}^{\circ} 5$ & 1 & 1 & 100.00 & 0.060 & 2 & 2 & 100.00 & 0.135 \\
\hline $\mathrm{N}^{\circ} 6$ & 2 & 1 & 50.00 & 0.000 & 12 & 4 & 33.33 & 0.058 \\
\hline $\mathrm{N}^{\circ} 7$ & 3 & 1 & 33.33 & 0.210 & 10 & 5 & 50.00 & 0.045 \\
\hline $\mathrm{N}^{\circ} 8$ & 5 & 5 & 100.00 & 0.142 & 1 & 1 & 100.00 & 0.370 \\
\hline Total & 54 & 20 & 37.04 & 0.100 & 87 & 31 & 35.62 & 0.075 \\
\hline
\end{tabular}

daily, the number of hours that the animals spend in the paddocks and in the box stalls, and the degree of inbreeding and the type of sport activities that the animals practice. We can and do wish that the results of the present study will lay the foundation for further research, to be carried out by extending the study to the hereditability of the characteristics, and to realize studies based on either candidate genes or genomewide association studies with the attempt to identify loci associated with the disorder.

\section{Acknowledgments}

This work is supported by grant of University of Pisa (Ateneo-Prof Francesca Cecchi and Prof. Adriano Podestà).

\section{Conflict of interest}

The authors declare that there is no conflict of interest. Author contributions

L.C.: concept/design, acquisition of data, drafting of the manuscript, assembled tables and figures, and approval of the article. A.P.: concept/design, critical revision of the manuscript, and approval of the article. C.R.: critical revision of the manuscript and approval of the article. C.F.: concept/design, statistical analysis, drafting of the manuscript, assembled tables and figures, critical revision of the manuscript, and approval of the article.

\section{References}

Avdi, M. and Banos, G. 2008. Genetic diversity and inbreeding in the Greek Skyros horse. Livest. Sci. $114,362-365$.

Brzeski, K.E., Rabon, D.R.J., Chamberlain, M.J., Waits, L.P. and Taylor, S.S. 2014. Inbreeding and inbreeding depression in endangered red wolfes (Canis rufus). Mol. Ecol. 23, 4241-4255.

Budzyński, M., Kamieniak, J., Chmiel, K. and Soltys, L. 1997. Inbreeding coefficients of purebred Arabian horses from Michałów Stud. Annales Universitatis Mariae Curie-Skłodowska Lublin 21, 141-147.

Bussiman, F.O., Perez, B.C., Ventura, R.V., Peixoto, M.G.C.D., Vizoná, R.F, Curi, R.A. and Balieiro,
J.C.C. 2018. Pedigree analysis and inbreeding effects over morphological traits in Campolina horse population. Anim. 12, 2246-2255.

Cecchi, F., Giacalone, G. and Paci, G. 2016. Inbreeding depression in Lizard canaries breed estimated by pedigree analysis. Czech J. Anim. Sci. 61, 15-21.

Cecchi, F., Carlini, G., Giuliotti, L. and Russo, C. 2018. Inbreeding may affect phenotypic traits in an Italian Population of Basset Hound dog. Rend. Lincei Sci. Fis. Nat. 29, 165-170.

Cervantes, I., Goyache, F., Molina, A., Valera, M. and Gutiérrez, J.P. 2008. Application of individual increase in inbreeding to estimate realized effective sizes from real pedigrees. J. Anim. Breed. Genet. 125(5), 301-310.

Ciampolini, R., Cecchi, F., Paci, G., Policardo, C. and Spaterna, A. 2013. Investigation on the Genetic Variability of the American Pit Bull Terrier dogs belonging to an Italian breeder using Microsatellite Markers and genealogical data. Cytol. Genet. 47(4), 217-221.

Curik, I., Zechner, P., Sölkner, J., Achmann, R., Bodo, I., Dovc, P., Kavar, T., Marti, E. and Brem, G. 2003. Inbreeding, microsatellite heterozygosity, and morphological traits in Lipizzan horses. J. Hered. 94, 125-132.

Dolvik, N.I. and Klemetsdal, G. 1994. Arthritis in the carpal joints of Norwegian trotter - heritability, effects of inbreeding and conformation. Livest. Prod. Sci. 39, 283-290.

Gandini, G.C., Bagnato, A., Miglior, F. and Pagnacco, G. 1992. Inbreeding in the Italian Haflinger horse. J. Anim. Breed. Genet. 109, 433-443.

Głażewska, I. 2004. Mating and selection in national Arabian horse breeding: inbreeding coefficients analysis. Electron J Polish Agric Univ. 7(1). Available at: http://www.ejpau.media.pl/volume7/ issue 1/animal/art-02.html.

Gómez, M.D., Valera, M., Molina, A., Gutiérrez, J.P. and Goyache, F. 2009. Assessment of inbreeding depression for body measurements in Spanish 
Purebred (Andalusian) horses. Livest. Sci. 122, 149-155.

Gonzales-Recio, O., Lopez de Maturana, E. and Gutierrez, J.P. 2007. Inbreeding depression on female fertility and calvin case in Spanish dairy cattle. J. Dairy Sci. 90, 5744-5752.

Gutiérrez, J.P. and Goyache, F. 2005. A note on ENDOG: a computer program for analysing pedigree information. J. Anim. Breed. Genet. 122, 172-176.

Hunt, R.J. 2011. Flexural limb deformities in foals, In: Diagnosis and management of lameness in the horse, 2nd ed. Eds., Ross, M.W. and Dyson, S.J. Philadelphia: W.B. Saunders, pp: 645-649.

Keller, L.F. and Waller, D.M. 2002. Inbreeding effects in wild populations. Trends Ecol. Evol. 17, 230241.

Langlois, B. and Blouin, C. 2004. Statistical analysis of some factors affecting the number of horse births in France. Reprod. Nutr. Dev. 44, 583-595.

O'Grady, S.E. and Poupard, D.A. 2003. Proper physiologic horseshoeing. Vet. Clin. North Am. Equine Pract. 19, 333-351.

O'Grady, S.E. 2012. Flexure Deformities of the distal interphalangeal jount (clubfeet). Equine Vet. Educ. $5,260-268$.

Redden, R.F. 2003. Hoof capsule distortion: Understanding the mechanism as a basis for rational mana. Equine Vet. Educ. 19, 443-463.

Sairanen, J., Nivola, K., Katila, T., Virtala, A.M. and Ojala, M. 2009. Effects of inbreeding and other genetic components on equine fertility. Anim. 3, $1662-1672$.

SAS-JMP. 2007. User's Guide, ver. Cary, NC: 7.0 SAS Inst.

Sargolzaei, M., Iwaisaki, H. and Colleau, J.J. 2006. CFC (Contribution, Inbreeding (F)), Coancestry, Release 1.0. A software package for pedigree analysis and monitoring genetic diversity. In Proc. 8th world cong. on genetics applied on livestock production, Belo Horizonte, Brazil, CD-ROM comm. N 27-28.

Schiele, E. 1970. The Arab Horse in Europe. London, UK: George G. Harrap \& CO.

Sierszchulski, J., Helak, M., Wolc, A., Szwaczkowski, T. and Schlote, W. 2005. Inbreeding rate and its effect on some conformation traits in Arabian mares. Anim. Sci. Pap. Rep. 23, 51-59.

Sobczyńska. M., 2010. Genetic parameters of racing performance indices in Polish Arabian horses. Livest. Sci. 131, 245-249.

Todd, E.T., Simon Y.W., Ho, S.Y.W., Thomson, P.C., Ang, R.A., Brandon, D., Velie, B.D., Natasha, A. and Hamilton, N.A. 2018. Founder-specific inbreeding depression affects racing performance in Thoroughbred horses. Sci. Rep. 8, 6167.

Vostrá-Vydrová, H., Vostrý, L., Hofmanová, B., Krupa, E. and Zavadilová, L. 2016. Pedigree analysis of the endangered Old Kladruber horse population. Livest. Sci. 185, 17-23.

Wolc, A. and Balińska, K. 2010. Inbreeding effects on exterior traits in Polish konik horses. Arch. Tierz. $53,1-8$. 